\title{
Effects of Badminton on Physical Developments of Males with Physical Disability*
}

\author{
Mehmet Fatih Yüksel \\ Faculty of Education, Necmettin Erbakan University, Konya, Turkey
}

Copyright $\bigcirc 2018$ by authors, all rights reserved. Authors agree that this article remains permanently open access under the terms of the Creative Commons Attribution License 4.0 International License

\begin{abstract}
This study was realized in order to determine the features of the male badminton players with physical disability, and to examine the effects of badminton on physical developments of individuals with physical disability. Totally 59 males voluntarily participated in the study, 35 of whom were male badminton players with physical disability $(n=35$, average exercise age; 4.9) and the rest were physically handicapped $(n=24)$ as the control group. Forming the research group, the male badminton players with physical disability, were divided into two groups according to the disability classification of the International Paralympic Committee, SL-3, SL-4, SU-5 (on foot, $\mathrm{n}=23$ ), and WH-1, WH-2 (on wheelchairs, $\mathrm{n}=12$ ). As for the control groups, physically handicapped individuals (on foot, $n=13$, wheelchair, $n=11$ ) of inactive lifestyle were included into the study. In order to determine the physical features of the participants following tests and measurements were applied; stature, weight, BMI, length of upper extremity, arm, fore arm and hand length, arm and forearm circumference, flexibility, balance, modified sit-up, modified abdominal endurance, hand grip strength, plate tapping, and modified push-up tests. Tests and measurements were applied on dominant hand and foot. At the end of the study, it was determined that there was a statistically significant difference in between badminton players on foot with disability (BMI, balance, modified sit-up, and modified push-up values) and players on wheelchair (BMI, forearm circumference, hand grip strength, and modified push-up values $),(\mathrm{p}<0.05)$. As a conclusion, it was determined that badminton develops physical features of the individuals with physical disability.
\end{abstract}

Keywords Badminton, Physically Handicapped, Physical Features

\section{Introduction}

It is a fact that sport increases interpersonal share, provides socializing and gaining recognition in the public. Actively participating in sports, a disabled individual not only empowers the body but also increases the life quality by empowering in terms of morale [1]. Sport activities for the disabled, contributes to the integration of the individual to the society. Sport activities for the innate disabled individuals, bring self-confidence. Accordingly sport activity for the disabled individuals is undeniable situation for the disabled individuals [2].

Increasing muscular force and endurance in disabled individuals, sport minimizes the development risk of musculoskeletal problems such as joint limitations or scoliosis that can be developed due to physical condition. Moreover, increasing the ability of use of devices such as prosthesis, crutch, or wheelchair that mobilize individuals in daily life, it provides them to be more independent in daily life $[3,4]$. Since the importance of the fact that sport has a positive effect on physical and psychological structure of the individuals was emphasized, the reality that sportive activities are vitally important also for the disabled individuals has gained acceptance. Today, there are numerous sport branches adapted for the disabled individuals. Badminton is one of the Paralympic sport branches that the disabled can participate in.

Badminton is one of the most favorite sport branches in the world that can be played in all age groups for recreation or tournament [5-7]. Being a contactless game and being among the Paralympic games of 2020 provided the quick spread of physically handicapped badminton. Particularly SL-4 and SL-5 categories in disabled badminton are fast and exciting sports having the same standards with normal badminton in terms of play rules and court size. Moreover, with hits like clear, smash, or drive which necessitate high effort particular to badminton, wheelchair badminton is characterized with high intensity activities like spinning the wheel, fast and sudden moves to back and front, and short sprints. In order to realize all of these abilities, the physical fitness level of the individual becomes important. When the literature is examined, it is observed that there are useful and helpful studies conducted on disabled players. Although there are many researches in different disabled sport branches [8-14], the physical fitness of physically disabled badminton 
players were not encountered.

Determining the physical features of physically disabled male badminton players, this research aimed to examine the effects of badminton sport on physical development of physically disabled individuals by making a comparison with the disabled individuals who did not deal with sport.

\section{Materials and Methods}

\subsection{Ethical Scope and Official Permits}

Necessary permissions regarding the tests and measurements were taken from the Federation Chairmanship, administrators and coaches of cities participating in the Physically Disabled Badminton Turkey Championship. Approval was obtained from the Ethics Committee (Report No: 2017/1032) at Necmettin Erbakan University Medical Faculty. All the volunteers participating in the research signed the informed consent and personal data form.

\subsection{Study Group}

In our study, physically disabled male badminton players ( $\mathrm{n}=35$, practice age average: 4.9 ) and control group comprised of physically disabled ( $\mathrm{n}=24)$, totally 59 males participated voluntarily.

According to the disability classification of the International Physically Disabled Badminton Federation, the players composing the experiment group were classified in two groups: SL-3, SL-4, SU-5 (on foot), and WH-1, WH-2 (on wheelchair). SS-6 category (dwarfs) was not included. Physically disabled individuals who did not deal with sports (on foot, $n=13$; and on wheelchair, $n=11$ ) comprised the control group of the study. Some limitations were applied considering the physical disability condition. Tests and measurements were applied on dominant hand and foot. Flamingo balance device was used for balance tests, but balance scores of the individuals on wheelchair could not recorded. Moreover, since 11 badminton players were amputee with one arm, only scores of 12 participants were measured in modified push-up test. Tests and protocols for determining the physical features of the participants were as follows.

\subsection{Data Collection Tools}

Height and Body weight: In the linear measurements a tapeline with $0.01 \mathrm{~m}$ sensitivity score was used. Weight measurements were made with a digital weighing scale with a sensitivity level of $0.01 \mathrm{~kg}$ [15].

Body mass index: Using body weights and lengths, BMI was determined using the BMI = Body weight/ (Length) ${ }^{2}$ formula [15].

Trunk length, upper extremity length, arm length, forearm length, hand length, arm circumference and forearm circumference measurements were made with tape and recorded in $\mathrm{cm}[16,17]$.

Trunk length: Determined by measuring the distance between the $\mathrm{C} 7$ and the coccyx.

Upper extremity length: Determined by measuring the distance between the Acromion and the tip of the longest finger on the hand.

Arm length: Determined by measuring the distance between the acromion and the olecranon while the shoulder and the arm were loose.

Forearm length: Determined by measuring the distance between the olecranon and styloid protrusion of radius.

Hand length: Determined by measuring the distance between the styloid protrusion of radius and the tip of the longest finger on the hand.

Arm circumference: Determined by locating the middle point of the distance between the acromion and olecranon, and measured while the muscles were loose.

Forearm circumference: Determined by locating the most swollen point of the muscle, and measured while the arm was loose.

Sit and reach test: was determined on the sit and reach platform, and recorded in $\mathrm{cm}$ [18].

Balance measurement: Balance scores were determined with Flamingo Balance device. Test lasted for one minute and at the end of the time, each balance attempt of the subject was counted and recorded as the balance result [19].

Modified Sit-up Test: The player positions himself lying on his back on the mat, knees bent, soles of the feet fully on the mat, hands on each side of the hips, and fingers in extension on the mat. The legs were supported as to keep the knees bent. The individual was asked for arising until the scapula bottom level, and do as many sit-ups as he could in 30 seconds [20,21].

Modified abdominal endurance: Lying on his back on the mat, the individual was asked for arising until scapula bottom level and keep this position as much as he could. The time was stopped and recorded, as the participant touched the scapula bottom level or deformed the position [22].

Hand grasping strength: Beginning from the right hand, the measurement was made with Jamar brand dynamometer and recorded in $\mathrm{kg}$, while the subject was on foot, arm straight with a $10-15^{\circ}$ angle from the shoulder on one side [18].

Plate tapping test: It was applied to measure the arm move speed. Two plastic discs (A and B) were placed on the table, $80 \mathrm{~cm}$ away from each other. Subject touched A, and B discs 25 times (totally 50 ) with the dominant hand as fast as possible. The timekeeper started as the subject touched disc A, and the value obtained at the end of the test was recorded in seconds [23].

Modified push up test: The participant was positioned as face down on the mat, and the modified push-up version for the females was applied. The power of upper extremity muscles of the subject and the number of rearward moves of upper body was recorded [22]. 


\subsection{Analyzing of Data}

SPSS 21.0 program was used in the analysis of the data obtained in the study. Arithmetic averages and standard deviations were given with descriptive statistics. The inter-group differences were detected via Mann-Whitney U test. Significance level was admitted as $(\mathrm{p}<0.05)$.

\section{Results}

Table 1. Average values of on foot disabled badminton players (1) and control group (2)

\begin{tabular}{|c|c|c|c|c|}
\hline VARIABLES & Group & $\mathrm{N}$ & Mean & Std. Deviation \\
\hline \multirow{2}{*}{ Age } & 1 & 23 & 31,52 & 14.57 \\
\hline & 2 & 13 & 36.00 & 9.56 \\
\hline \multirow{2}{*}{ Training age } & 1 & 23 & 4,82 & 4,17 \\
\hline & 2 & 13 & 0.00 & 0.00 \\
\hline \multirow{2}{*}{ Height } & 1 & 23 & 174,86 & 7.24 \\
\hline & 2 & 13 & 170.15 & 6.29 \\
\hline \multirow{2}{*}{ Weight } & 1 & 23 & 70.86 & 7.00 \\
\hline & 2 & 13 & 75.46 & 6.15 \\
\hline \multirow{2}{*}{ BMI } & 1 & 23 & 23.25 & 2.76 \\
\hline & 2 & 13 & 26.11 & 2.31 \\
\hline \multirow{2}{*}{ Upper extremity length } & 1 & 23 & 80.15 & 4.29 \\
\hline & 2 & 13 & 80.50 & 4.72 \\
\hline \multirow{2}{*}{ Arm length } & 1 & 23 & 31.84 & 1.86 \\
\hline & 2 & 13 & 31.92 & 1.75 \\
\hline \multirow{2}{*}{ Forearm length } & 1 & 23 & 26.82 & 2.06 \\
\hline & 2 & 13 & 27.07 & 1.74 \\
\hline \multirow{2}{*}{ Hand length } & 1 & 23 & 21.47 & 1.32 \\
\hline & 2 & 13 & 21.50 & 1.42 \\
\hline \multirow{2}{*}{ Arm circumference } & 1 & 23 & 29.71 & 2.68 \\
\hline & 2 & 13 & 30.42 & 1.98 \\
\hline \multirow{2}{*}{ Forearm circumference } & 1 & 23 & 28.50 & 1.98 \\
\hline & 2 & 13 & 28.15 & 1.66 \\
\hline \multirow{2}{*}{ Flexibility } & 1 & 23 & 25.56 & 9.81 \\
\hline & 2 & 13 & 20.92 & 8.29 \\
\hline \multirow{2}{*}{ Balance } & 1 & 23 & 4.73 & 2.54 \\
\hline & 2 & 13 & 8.53 & 2.33 \\
\hline \multirow{2}{*}{ Modified sit-up } & 1 & 23 & 27.60 & 6.25 \\
\hline & 2 & 13 & 21.61 & 5.78 \\
\hline \multirow{2}{*}{ Modified abdominal endurance } & 1 & 23 & 89.76 & 32.54 \\
\hline & 2 & 13 & 85.47 & 28.81 \\
\hline \multirow{2}{*}{ Hand grasping strength } & 1 & 23 & 56.23 & 11.03 \\
\hline & 2 & 13 & 54.65 & 10.96 \\
\hline \multirow{2}{*}{ Plate tapping } & 1 & 23 & 11.29 & 2.40 \\
\hline & 2 & 13 & 11.74 & 2.32 \\
\hline \multirow{2}{*}{ Modified push up } & 1 & 12 & 29.58 & 7.21 \\
\hline & 2 & 13 & 23.23 & 5.86 \\
\hline
\end{tabular}


Table 2. Mann Whitney U analysis results of on foot disabled badminton players (1) and control group (2)

\begin{tabular}{|c|c|c|c|c|c|}
\hline VARIABLES & Group & $\mathrm{N}$ & Mean Rank & $\mathrm{U}$ & $\mathrm{p}$ \\
\hline \multirow{2}{*}{ Age } & 1 & 23 & 16.70 & \multirow{2}{*}{108.000} & \multirow{2}{*}{0.171} \\
\hline & 2 & 13 & 21.69 & & \\
\hline \multirow{2}{*}{ Height } & 1 & 23 & 21.07 & \multirow{2}{*}{90.500} & \multirow{2}{*}{0,051} \\
\hline & 2 & 13 & 13.96 & & \\
\hline \multirow{2}{*}{ Weight } & 1 & 23 & 16.09 & \multirow{2}{*}{94.000} & \multirow{2}{*}{0.067} \\
\hline & 2 & 13 & 22.77 & & \\
\hline \multirow{2}{*}{ BMI } & 1 & 23 & 14.65 & \multirow{2}{*}{61.000} & \multirow{2}{*}{$0.004 *$} \\
\hline & 2 & 13 & 25.31 & & \\
\hline \multirow{2}{*}{ Upper extremity length } & 1 & 23 & 18.67 & \multirow{2}{*}{145.500} & \multirow{2}{*}{0.895} \\
\hline & 2 & 13 & 18.19 & & \\
\hline \multirow{2}{*}{ Arm length } & 1 & 23 & 18.50 & \multirow{2}{*}{149.500} & \multirow{2}{*}{0.980} \\
\hline & 2 & 13 & 18.50 & & \\
\hline \multirow{2}{*}{ Forearm length } & 1 & 23 & 18.20 & \multirow{2}{*}{142.500} & \multirow{2}{*}{0.816} \\
\hline & 2 & 13 & 19.04 & & \\
\hline \multirow{2}{*}{ Hand length } & 1 & 23 & 18.57 & \multirow{2}{*}{148.000} & \multirow{2}{*}{0.960} \\
\hline & 2 & 13 & 18.38 & & \\
\hline \multirow{2}{*}{ Arm circumference } & 1 & 23 & 17.41 & \multirow{2}{*}{124.500} & \multirow{2}{*}{0.408} \\
\hline & 2 & 13 & 20.42 & & \\
\hline \multirow{2}{*}{ Forearm circumference } & 1 & 23 & 19.02 & \multirow{2}{*}{137.500} & 0601 \\
\hline & 2 & 13 & 17.58 & & 0.091 \\
\hline Fleyibility & 1 & 23 & 20.35 & 107000 & 0161 \\
\hline Fiexionitity & 2 & 13 & 15.23 & 107.000 & 0.101 \\
\hline Dolomo & 1 & 23 & 13.67 & 20500 & $0000 *$ \\
\hline Dalaince & 2 & 13 & 27.04 & 30.000 & 0.000 \\
\hline Modified citun & 1 & 23 & 21.89 & 71500 & $0010 *$ \\
\hline 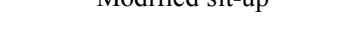 & 2 & 13 & 12.50 & 11.000 & 0.010 \\
\hline Modifiod obdominol onduronc & 1 & 23 & 19.19 & 140500 & 0767 \\
\hline & 2 & 13 & 18.11 & 140.000 & 0.101 \\
\hline Hond ancina ctonotb & 1 & 23 & 19.23 & $140 \Omega 00$ & 0.754 \\
\hline Hand grasping stivingur & 2 & 13 & 18.09 & 170.000 & ד. \\
\hline Dlate tonning & 1 & 23 & 17.70 & 121000 & 0.542 \\
\hline I lat tapping & 2 & 13 & 19.92 & 101.000 & 0.342 \\
\hline Modified nuch un & 1 & 12 & 16.67 & 24000 & $0016 *$ \\
\hline 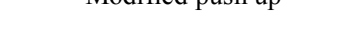 & 2 & 13 & 9.62 & 34.000 & 0.010 \\
\hline
\end{tabular}

$* \mathrm{p}<0.05$

When the Table 2 is examined, it was determined that there were statistically significant differences in between experimental group and control group in BMI $(U=61.000, p<0.05)$, flamingo balance $(U=38.500$, $p<0.05)$, modified sit-ups $(U=71.500, p<0.05)$ and modified push-up $(U=34.000, p<0.05)$ parameters, and that there was not a statistically significant difference between the other parameters. 
Table 3. Average values of on wheelchair disabled badminton players (1) and control group (2)

\begin{tabular}{|c|c|c|c|c|}
\hline VARIABLES & Group & $\mathrm{N}$ & Mean & Std. Deviation \\
\hline \multirow{2}{*}{ Age } & 1 & 12 & 32.41 & 10.11 \\
\hline & 2 & 11 & 38.18 & 10.82 \\
\hline \multirow{2}{*}{ Training age } & 1 & 12 & 5.08 & 4.98 \\
\hline & 2 & 11 & 0.00 & 0.00 \\
\hline \multirow{2}{*}{ Height } & 1 & 12 & 168.16 & 9.83 \\
\hline & 2 & 11 & 165.09 & 8.01 \\
\hline \multirow{2}{*}{ Weight } & 1 & 12 & 61.58 & 7.56 \\
\hline & 2 & 11 & 65.81 & 10.24 \\
\hline \multirow{2}{*}{ BMI } & 1 & 12 & 21.77 & 2.20 \\
\hline & 2 & 11 & 24.05 & 2.68 \\
\hline \multirow{2}{*}{ Upper extremity length } & 1 & 12 & 78.87 & 1.90 \\
\hline & 2 & 11 & 77.59 & 2.72 \\
\hline \multirow{2}{*}{ Arm length } & 1 & 12 & 30.70 & 1.68 \\
\hline & 2 & 11 & 29.81 & 1.50 \\
\hline \multirow{2}{*}{ Forearm length } & 1 & 12 & 27.83 & 1.23 \\
\hline & 2 & 11 & 27.18 & 1.12 \\
\hline \multirow{2}{*}{ Hand length } & 1 & 12 & 21.00 & 0.92 \\
\hline & 2 & 11 & 20.59 & 0.97 \\
\hline \multirow{2}{*}{ Arm circumference } & 1 & 12 & 33.95 & 4.29 \\
\hline & 2 & 11 & 32.72 & 3.78 \\
\hline \multirow{2}{*}{ Forearm circumference } & 1 & 12 & 31.37 & 2.59 \\
\hline & 2 & 11 & 28.90 & 2.50 \\
\hline \multirow{2}{*}{ Flexibility } & 1 & 12 & 34.08 & 12.99 \\
\hline & 2 & 11 & 29.72 & 11.12 \\
\hline \multirow{2}{*}{ Modified sit-up } & 1 & 12 & 29.50 & 4.58 \\
\hline & 2 & 11 & 25.63 & 4.27 \\
\hline \multirow{2}{*}{ Modified abdominal endurance } & 1 & 12 & 114.50 & 46.78 \\
\hline & 2 & 11 & 108.27 & 51.04 \\
\hline \multirow{2}{*}{ Hand grasping strength } & 1 & 12 & 54.16 & 8.55 \\
\hline & 2 & 11 & 45.18 & 8.26 \\
\hline \multirow{2}{*}{ Plate tapping } & 1 & 12 & 11.98 & 2.65 \\
\hline & 2 & 11 & 12.37 & 2.62 \\
\hline \multirow{2}{*}{ Modified push up } & 1 & 12 & 27.33 & 6.03 \\
\hline & 2 & 11 & 22.90 & 3.96 \\
\hline
\end{tabular}


Table 4. Mann Whitney U analysis results of on wheelchair disabled badminton players (1) and control group (2)

\begin{tabular}{|c|c|c|c|c|c|}
\hline VARIABLES & Group & $\mathrm{N}$ & Mean Rank & $\mathrm{U}$ & $\mathrm{p}$ \\
\hline \multirow{2}{*}{ Age } & 1 & 12 & 9.92 & \multirow{2}{*}{41.000} & \multirow{2}{*}{0.123} \\
\hline & 2 & 11 & 14.27 & & \\
\hline \multirow{2}{*}{ Height } & 1 & 12 & 13.33 & \multirow{2}{*}{50.000} & \multirow{2}{*}{0.321} \\
\hline & 2 & 11 & 10.55 & & \\
\hline \multirow{2}{*}{ Weight } & 1 & 12 & 9.83 & \multirow{2}{*}{40.000} & \multirow{2}{*}{0.109} \\
\hline & 2 & 11 & 14.36 & & \\
\hline \multirow{2}{*}{ BMI } & 1 & 12 & 9.25 & \multirow{2}{*}{33.000} & \multirow{2}{*}{$0.042 *$} \\
\hline & 2 & 11 & 15.00 & & \\
\hline \multirow{2}{*}{ Upper extremity length } & 1 & 12 & 14.25 & \multirow{2}{*}{39.000} & \multirow{2}{*}{0.095} \\
\hline & 2 & 11 & 9.55 & & \\
\hline \multirow{2}{*}{ Arm length } & 1 & 12 & 13.83 & \multirow{2}{*}{44.000} & \multirow{2}{*}{0.172} \\
\hline & 2 & 11 & 10.00 & & \\
\hline \multirow{2}{*}{ Forearm length } & 1 & 12 & 13.83 & \multirow{2}{*}{44.000} & \multirow{2}{*}{0.170} \\
\hline & 2 & 11 & 10.00 & & \\
\hline \multirow{2}{*}{ Hand length } & 1 & 12 & 13.71 & \multirow{2}{*}{45.500} & \multirow{2}{*}{0.198} \\
\hline & 2 & 11 & 10.14 & & \\
\hline \multirow{2}{*}{ Arm circumference } & 1 & 12 & 13.21 & \multirow{2}{*}{51.500} & \multirow{2}{*}{0.371} \\
\hline & 2 & 11 & 10.68 & & \\
\hline \multirow{2}{*}{ Forearm circumference } & 1 & 12 & 15.00 & \multirow{2}{*}{30.000} & \multirow{2}{*}{$0.026 *$} \\
\hline & 2 & 11 & 8.73 & & \\
\hline Flexibility 5 o & 1 & 12 & 13.83 & 44000 & 0175 \\
\hline Fiexionitily & 2 & 11 & 10.00 & 44.000 & 0.173 \\
\hline Modified cit un & 1 & 12 & 14.88 & 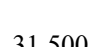 & $0032 *$ \\
\hline 1970ता & 2 & 11 & 8.86 & 51.000 & $0.0 \mathrm{JJ}$ \\
\hline Modified obdominal ondurance & 1 & 12 & 12.63 & 58500 & 0644 \\
\hline & 2 & 11 & 11.32 & 30.000 & 0.047 \\
\hline Hond orecning ctronotb & 1 & 12 & 15.54 & 23500 & $0000 *$ \\
\hline Ha & 2 & 11 & 8.14 & 25.500 & 0.000 \\
\hline Dlote tomino & 1 & 12 & 11.46 & 50.500 & 0609 \\
\hline 1 1ate tapping & 2 & 11 & 12.59 & 39.000 & 0.000 \\
\hline Modified nuch un & 1 & 12 & 12.38 & 32000 & $0025 *>>>2>0$ \\
\hline Nodined pusn up & 2 & 11 & 11.59 & 32.000 & 0.053 \\
\hline
\end{tabular}

$* \mathrm{p}<0.05$

When the Table 4 is examined, it was determined that there were statistically significant differences in between experimental group and control group in BMI $(\mathrm{U}=61.000$, $\mathrm{p}<0.05)$, forearm circumference $(\mathrm{U}=30.000, \mathrm{p}<0.05)$, modified sit-ups $(\mathrm{U}=31.500, \mathrm{p}<0.05)$, hand grasping power $(\mathrm{U}=23.500, \mathrm{p}<0.05)$, and modified push-up $(\mathrm{U}=32.000$, $\mathrm{p}<0.05$ ) parameters, and that there was not a statistically significant difference between the other parameters.

\section{Discussion and Conclusions}

This research aimed determine the physical features of physically disabled male badminton players, and to examine the effects of badminton sport on physical development of physically disabled individuals by making a comparison with the disabled individuals who did not deal with sport.

It was observed that the values of badminton players on foot and on wheelchair, and the values of disabled individuals not dealing with sport were similar in anthropometric measurements. It was observed that there was statistically difference between on foot badminton players and disabled individuals without sport activity, in terms of BMI, balance, modified sit-up, and modified push-up parameters; between wheelchair badminton players and disabled individuals without sport activity, in terms of BMI, forearm circumference, modified sit-ups, 
hand grasping power, and modified push-up parameters. Ergun and Baltac1 [22] reported that sport could be used to gain coordination, freedom in movements, muscle control, and balance in disabled rehabilitation. Silfies et al. [24] mentioned that core stability has the ability to control the movement and position of the body during the functional activity. Tolfrey et al. [25] reported that cardiovascular endurance levels of the wheelchair players was correlated with body mass, adipose tissue, and body control. In this study, the abdominal power and endurance levels of the participants were examined, and it was determined that abdominal power values of both on foot and wheelchair badminton players were statistically significantly better. For abdominal endurance levels, it was determined that there was not a statistically significant difference compared to the individuals without sport; however, it was determined that they had better values than individuals without sport. In a similar study on amputee football players, positive correlation was determined between upper body muscle stabilization and upper body flexor muscle power, and it was mentioned that upper body stabilization, balance and upper body muscle power practices must be included in exercise programs [26].

It was reported that strengthening and stretching exercises would be useful in disabled individuals [27]. Although flexibility average values of both groups physically disabled badminton players were determined to be higher compared to individuals without sport, not a statistically significant difference was observed. This could be stemmed from badminton players not doing sufficient flexibility exercises in their practices. In badminton sport branch, flexibility of upper body muscles, upper and lower extremity provides many advantages to the player. Flexibility of the muscles and joint movement variety play important role particularly in difficult positions like over-head hits that a player can encounter during a rally and while doing a technique movement. In other studies on physically disabled individuals, it was mentioned that upper body and extremity muscles shoulder significant burden during daily activities particularly like pushing the wheelchair, over repetition, and transfer; thus the endurance and power of the upper extremities were also important [28-31]. The observation of the study that 'there was statistically difference between on foot badminton players and disabled individuals without sport activity, in terms of BMI, balance, modified sit-up, and modified push-up parameters; between wheelchair badminton players and disabled individuals without sport activity in terms of BMI, forearm circumference, modified sit-ups, hand grasping power, and modified push-up parameters' can be explained with the result that badminton sport provides development of upper body and upper extremity muscles particularly in physically disabled individuals. Contrary to some studies on basketball players with wheelchair [32-34] that reported right and left hand grasping powers in between $27-51 \mathrm{~kg}$, it was observed in this study that the hand grasping power values obtained from both of the badminton player groups were quite higher. The reason of this is thought to be the result of special hand grasping power enhancing practices, since hand grasping power is vital in many parts of the game, and due to the necessity to grasp the racquet tighter in some technique hits (drive, net-kill, smash).

Moving in complete independency is vital for a physically disabled individual. When disabled individuals who deal or do not deal with sports are compared, it is observed that the ones dealing with sports are more independent in terms of mobility, have higher social participation, and have higher life quality compared to individuals who do not deal with sports $[35,36]$. Hutzler et al. [37] reported that regular exercises of an individual were effective on physical fitness.

Being the first research on the physical features of physically disabled badminton players on foot and on wheelchair and having been reached to some results is the strength of this study. However, disabled badminton players both on foot and on wheelchair do not form a homogenous group. These individuals have pathologies differentiating their functional levels. Their functional characteristics may differ even if they have the same disability. From this point of view, classifying the physically disabled badminton players as on foot and on wheelchair can be accepted as the weakness of the study.

As a conclusion, it was determined that badminton sport develops bio-motor features of physically disabled individuals. Moreover, considering the importance of orientation of disabled individuals, who are deprived of some physical faculties, to the social life, it can be mentioned that badminton sport has positive contributions to the increase in their physical fitness.

\section{REFERENCES}

[1] T. A. Kalyon. Özürlülerde Spor, Bağırgan Yayımevi, Ankara, 1997.

[2] M. Atay. Engelli bireylerin benlik gelişiminde spor etkinliklerinin önemi. Uluslararas1 Engellilerde Spor Sempozyumu Bildiri Kitabı, GSGM Spor Eğitim Dairesi Başkanlığı Yayınları, Antalya, 1995.

[3] F. Di Russo, A. Bultrini, S. Brunelli, A.S. Delussu, L. Polidori, F. Taddei, M. Traballesi, D. Spinelli. Benefits of sports participation for executive function in disabled athletes, Journal of Neurotrauma, Vol.27, No.12, 2309-2319, 2010.

[4] D. R. Shapiro, J. J. Martin. Athletic identity, affect, and peer relations in youth athletes with physical disabilities, Disabil Health J, Vol.3, No.2, 79-85, 2010.

[5] B. S. Sucharitha, A. V. Reddy, K. Madhavi. Effectiveness of plyometric training on anaerobic power and agility in female badminton players, International Journal of 
Pharmaceutical Research and Bio-Science, Vol.3, No.4, 754-761, 2014.

[6] J. A. Vicen, J. Del Coso, C. G. Millan, J. J. Salinero, P. Abian. Analysis of dehydration and strength in elite badminton Players, Plos One Journal, Vol.7, No.5, 1-8, 2012.

[7] B. F. Yousif, K. S. Yeh. Badminton training machine with impact mechanism, Journal of Engineering Science and Technology, Vol.6, No.1, 61 - 68, 2011.

[8] E. Cömert, N. Ün Yıldırım, N. Ergun. Evaluation of upper extremity functionality in wheelchair basketball sport, Türkiye Klinikleri J Sports Sci, Vol.2, No.2, 62-69, 2010.

[9] M. Protic, H. Valkova. Psychosocial aspects of player's engagement to the sitting volleyball, Acta Kinesiologica, Vol.5, No.2, 12-16, 2011.

[10] B. Akınoğlu, T. Kocahan, T. Birben, Ö. Çoban, C.. Soylu, N. Ün Yildırım. Comparison of core stabilization the Paralympic archers and Paralympic wheelchair basketball Players, Online Turkish Journal of Health Science, Vol.1, No.3, 21-27, 2016.

[11] Z. Güçhan Topcu, K. Bayramlar, N. Ergun, Y. Ercan. Comparison of mobility and quality of life levels in sedentary amputees and amputee soccer players, Journal of Exercise Therapy and Rehabilitation, Vol.4, No.2, 47-53, 2017.

[12] I. Mahmutovic, S. Delalic, S. Uslu, M. Ibrahimovic, A. Tabakovic. Impact of morphological characteristics on the situational-motor abilities of sitting volleyball players, International Journal of Science Culture and Sport, Vol.3, No.1, 29-33, 2015.

[13] A. Darilgen, N. Ün Yildırım. Assessment of physical fitness in wheelchair basketball Players, Fizyoter Rehabil, Vol.19, No.2, 64-73, 2008.

[14] J. Marszalek, B. Molik, M. A. Gomez, K. Skucas, J. Lencse-Mucha, W. Rekowski, V. Pokvytyte, I. Rutkowska, K. Kazmierska-Kowalewska. Relationships between anaerobic performance, field tests and game performance of sitting volleyball players, Journal of Human Kinetics, Vol.48, 25-32, 2015.

[15] E. Zorba, Ö. Saygın. Fiziksel Aktivite ve Fiziksel Uygunluk. (2. Bask1), İnceler Ofset, İstanbul, 2009.

[16] R. Easterby, K. H. E. Kroemer, D. B. Chaffin. (Ed). Anthropometry and Biomechanics, Plenum Press, New York and London, 1982.

[17] A. S. Otman, H. Demirel, A. Sade. Tedavi Hareketlerinde Temel Değerlendirme Prensipleri, Hacettepe Üniversitesi Fizik Tedavi ve Rehabilitasyon Yüksekokulu Yayınları, Ankara, 1995.

[18] M. Günay, K. Tamer, İ. Cicioğlu. Spor Fizyolojisi ve Performans Ölçümü (3. Bask1), Gazi Kitabevi, Ankara, 2013.

[19] N. Tsigilis, H. Douda, S. P. Tokmakidis. Test-retest reliability of the eurofit test battery administered to university students, Perceptual and Motor Skills, Vol.95, 1295-1300, 2002.

[20] M. E. Sahlberg, U. Svantesson, E. M. Thomas, B. Strandvik.
Muscular strength and function in patients with cystic fibrosis, Chest, Vol.127, No.5, 1587-1592, 2005.

[21] D. Tomchuk. Companion Guide to Measurement and Evaluation for Kinesiology, Jones \& Bartlett Learning, Canada, 2011.

[22] N. Ergun, G. Baltac1. Spor Yaralanmalarında Fiztoyetrapi ve Rehabilitasyon Prensipleri (2. bask1), Hacettepe Üniversitesi Fizik Tedavi ve Rehabilitasyon Yüksekokulu Yayınları, Ankara, 2006.

[23] C. Adam. Eurofit: handbook for the Eurofit tests of physical fitness, Italian National Olympic Committee, Central Direction for Sport's Technical Activities Documentation and Information Division, Rome, 1988.

[24] S. P. Silfies, D. Ebaugh, M. Pontillo, C. M. Butowicz. Critical review of the impact of core stability on upper extremity athletic injury and performance, Braz J Phys Ther, Vol.19, No.5, 360-368, 2015.

[25] V. L. Tolfrey, A. M. Batterham, K. Tolfrey. Scaling behavior of VO2 peak in trained wheelchair athletes, Med. Sci. Sports Exerc, Vol.35, No.12, 2106-2111, 2003.

[26] A. Aytar, N. O. Pekyavas, N. Ergun, M. Karatas. Is there a relationship between core stability, balance and strength in amputee soccer players? A pilot study, Prosthet Orthot Int, Vol.36, No.3, 332-338, 2012.

[27] L. M. Olenik, J. J. Laskin, R. Burnham, G. D. Wheeler, R. D. Steadward. Efficacy of rowing, backward wheeling and isolated scapular retractor exercise as remedial strength activities for wheelchair users, Paraplegia, Vol.33, No.3, 148-152, 1995.

[28] K. Kulig, C. J. Newsam, S. J. Mulroy, S. Rao, J. K. Gronley, E. L. Bontrager, J. Perry. The effect of level of spinal cord injury on shoulder joint kinetics during manual wheelchair propulsion, Clin Biomech, Vol.16, No.9, 744-51, 2001.

[29] K. A. Samuelsson, H. Tropp, B. Gerdle. Sholder pain and its consequences in paraplegic spinal cord-injured, wheelchair users, Spinal Cord, Vol.42, No.1, 41-46, 2004.

[30] S. Van Drongelen, S. De Groot, H. E. Veeger, E. L. Angenot, A. J. Dallmeijer, M. W. Post, L. H. Woude. Upper extremity musculoskeletal pain during and after rehabilitation in wheelchair-using persons with a spinal cord injury, Spinal Cord, Vol.44, No.3, 152-9, 2006.

[31] H. E. J. Veeger, L. A. Rozendaal, F. C. T. Van der Helm. Load on the shoulder in low intensity wheelchair propulsion, Clin Biomech, Vol.17, 211-218, 2002.

[32] M. Akgün, H. Akdur, S. İnal, Z. Yiğit. Türkiye bedensel engelliler tekerlekli sandalye basketbolu 1 . ve 2 . liginde yer alan iki takım oyuncularının fiziksel uygunluk parametrelerinin karşılaştırılması, The 10th ICHPER-SD European Congress and the TSSA 8th International Sports Science Congress, Antalya, Turkey, 2004.

[33] R. A. Cooper, L. A. Quatrano, P. W. Axelson, W. Harlan, M. Stineman, B. Franklin, J. S. Krause, J. Bach, H. Chambers, E. Y. Chao, M. Alexander, P. Painter. Research on physical activity and health among people with disabilities: A consensus statement, J of Rehabil Res Dev, Vol.36, No.2, 142-154, 1999.

[34] N. Ergun, İ. Düzgün, E. Aslan. Effect of the number of 
years of experience on Physical fitness, sports skills and quality of life in wheelchair basketball Players, Turkish Journal of Physiotherapy and Rehabilition, Vol.19, No.2, $55-63,2008$.

[35] B. Wilhite, J. Shank. In praise of sport: promoting sport participation as a mechanism of health among persons with a disability, Disabil Health J, Vol.2, No.3, 116-127, 2009.

[36] K. Yazıcığlu, F. Yavuz, A. S. Göktepe, A. K. Tan.

*Part of this research was carried out in Konya-Turkey 20-21 October $2017, " 3^{\text {rd }}$ International Physical Education and Sports Conference for the Disabled" was presented as oral presentation.
Influence of adapted sports on quality of life and life satisfaction in sport participants and non-sport participants with physical disabilities, Disabil Health J, Vol.5, No.4, 249-253, 2012.

[37] Y. Hutzler, S. Ochana, R. Bolotin, E. Kalina. Aerobic and anaerobic arm-cranking power outputs of males with lower limb impairments: relationship with sport participation intensity, age, impairment and functional Classification, Spinal Cord, Vol.36, No.3, 205-12, 1998. 